\title{
Personal protective equipment (PPE) in a pandemic: Approaches to PPE preservation for South African healthcare facilities
}

\author{
C le Roux, ${ }^{1} \mathrm{MB} \mathrm{ChB}$, student intern; A Dramowski, ${ }^{2} \mathrm{MB} \mathrm{ChB}, \mathrm{FC}$ Paed (SA), MMed (Paed), Cert ID (SA) Paed, DCH, PhD \\ ${ }^{1}$ Faculty of Medicine and Health Sciences, Stellenbosch University, Cape Town, South Africa \\ ${ }^{2}$ Division of Paediatric Infectious Diseases, Department of Paediatrics and Child Health, Faculty of Medicine and Health Sciences, \\ Stellenbosch University, Cape Town, South Africa
}

Corresponding author: A Dramowski (dramowski@sun.ac.za)

\begin{abstract}
Personal protective equipment (PPE) is key to protecting healthcare workers from COVID-19 infection, but the pandemic has disrupted supply chains globally and necessitated rapid review of the scientific evidence for PPE re-use. In South Africa, where the COVID-19 epidemic is still developing, healthcare facilities have a short window of opportunity to improve PPE supply chains, train staff on prudent PPE use, and devise plans to track and manage the inevitable increases in PPE demand. This article discusses the available PPE preservation strategies and addresses the issue of decontamination and re-use of N95 respirators as a last-resort strategy for critical shortages during the pandemic.
\end{abstract}

S Afr Med J 2020;110(6):466-668. https://doi.org/10.7196/SAMJ.2020.v110i6.14831

Healthcare workers (HCWs) are at high risk of COVID-19 infection, with 22073 cases in HCWs from 52 countries reported to the World Health Organization (WHO) by early April 2020. ${ }^{[1,2]}$ Continuous availability of personal protective equipment (PPE), correct PPE application/removal and appropriate decontamination of re-usable PPE are key to protecting HCWs from infectious pathogens, including COVID-19.

The current pandemic has challenged PPE supply chains globally and necessitated rapid review of the scientific evidence for PPE use and re-use. Both the WHO and the US Centers for Disease Control and Prevention have updated their guidance on PPE preservation strategies in the face of critical shortages. ${ }^{[3-6]}$ As South African (SA) healthcare facilities develop contingency plans for expected PPE shortages, the following tiered PPE preservation strategies should be considered:

- Restricted use: use PPE as recommended in the national infection prevention guidelines, ${ }^{[7]}$ minimise access of visitors to healthcare facilities, cohort staff to COVID high- v. low-risk areas, and limit the number of staff performing aerosol-generating procedures, e.g. one staff member performs COVID-19 testing.

- Extended use: use PPE for longer periods of time than normally recommended and/or while caring for several different patients without removal, e.g. visors and surgical masks.

- Procurement of alternative or emergency replacement PPE, e.g. 3D printed face shields, and plastic rain ponchos or refuse bags to replace aprons.

- Use of PPE after the manufacturer-designated shelf-life, e.g. use of masks after the expiry date.

- Procurement of re-usable PPE, e.g. goggles or re-usable plastic visors instead of disposable visors.

- Re-use of PPE: this involves the decontamination of PPE items that would normally be disposed of after use (single-use items), e.g. N95 respirators. Re-use should only be considered as a last resort when PPE supplies are about to run out and there are no alternatives available. Re-use of PPE in COVID-19 critical care settings should be avoided owing to increased risk of HCW infection.

In SA, where the COVID-19 epidemic is still developing, healthcare facilities have a short window of opportunity to improve PPE supply chains, train staff on prudent PPE use, and devise plans to track and manage the inevitable increases in PPE demand. Restricted use of PPE should be implemented in all facilities. This effort would be aided by the use of non-medical (cloth) masks for visitors and administrative staff, ${ }^{[8,9]}$ and preserving medical masks for frontline workers.

For public sector SA HCWs exposed to tuberculosis, extended use of N95 respirators is already practised, with continuous use over 1 day or intermittent use over 1 week, if respirator integrity and the seal is maintained. This extended-use policy applies to COVID-19, with the same caveats of respirator integrity, an intact seal, appropriate storage (labelled paper bag or envelope), and thorough hand hygiene when donning and removing the respirator. Respirators should not be shared between HCWs. ${ }^{[3,6]}$ Surgical mask use can be extended to a single shift, particularly for HCWs with minimal close patient contact. Most face shields, visors and goggles are suitable for re-use following careful decontamination (soap and water cleaning, followed by disinfection with $70 \%$ alcohol). Re-usable face shields are preferable to goggles and disposable shields as they reduce droplet contamination of the mask/respirator. For COVID-19 intensive care wards, extended use of gowns for the duration of the shift is permissible. Aprons should preferably be changed between patient care activities, especially when contaminated with respiratory secretions or body fluids; aprons are not suitable for re-use. Gloves cannot be re-used and should be changed between each patient contact, followed by thorough hand hygiene. ${ }^{[3]}$

There is a limited evidence base to guide methods for decontamination of N95 respirators, although new data are rapidly emerging and commercial systems are being developed. ${ }^{[10-12]}$ Decontamination of N95 respirators should only be considered 
as a last resort to ensure a supply of N95 respirators for HCWs performing aerosol-generating procedures on patients with suspected/confirmed COVID-19. Problems with respirator re-use following decontamination include an inadequate seal (following wear or damage to the elastic straps), damage to the integrity of filter fibres, and lack of local testing to verify virus and particle filtration efficiency after respirator processing. ${ }^{[5,6]}$ In most lowresource settings, N95 respirator decontamination is unlikely to be feasible or affordable, and it is at best a stop-gap approach until a supply of new respirators is assured. Should SA healthcare facilities embark on N95 respirator decontamination programmes, the costs, feasibility, reproducibility and safety of the available methods should be carefully considered (Table 1).

An urgent and critical review of healthcare facility PPE supply and preservation strategies should be undertaken at every SA healthcare facility, incorporating national and international recommendations. ${ }^{[3-4,7]}$ Restricted use, extended use, procurement of re-usable PPE and development of alternative PPE items should remain the focus of local PPE preservation activities. However, decontamination to enable re-use of N95 respirators could be a last resort strategy for critical shortages during the pandemic. Current obstacles to implementing N95 respirator decontamination in SA and other low-resource settings are the substantial financial costs and lack of available technology for rapid implementation. Given the heightened risk of COVID-19 infection in HCWs and potential PPE shortages, SA healthcare facilities should actively implement PPE preservation approaches and consider options for N95 respirator decontamination should a supply crisis occur.

\section{Declaration. None.}

Acknowledgements. None.

Author contributions. $\mathrm{ClR}$ and $\mathrm{AD}$ conceptualised the manuscript, $\mathrm{ClR}$ reviewed the current evidence base, both authors drafted and revised the manuscript.

Funding. $\mathrm{AD}$ is supported by a National Institutes of Health Fogarty Emerging Global Leader Award (K43TW010682).

Conflicts of interest. None.

Table 1. Methods for reprocessing of N95 respirators during critical shortages

\begin{tabular}{|c|c|c|}
\hline $\begin{array}{l}\text { Disinfection } \\
\text { method }\end{array}$ & $\begin{array}{l}\text { Equipment requirements, processing } \\
\text { time and volume }\end{array}$ & Advantages and disadvantages \\
\hline $\begin{array}{l}\text { Hydrogen peroxide } \\
\text { vapour }\end{array}$ & $\begin{array}{l}\text { - Hydrogen peroxide vapour generator, } \\
\text { e.g. Sterrad or Bioquell Clarus }{ }^{[3]} \\
\text { - A sealed chamber } \\
\text { - 8-hour processing time, including } \\
\text { conditioning, gassing, dwell and } \\
\text { aeration phases }^{[10]}\end{array}$ & $\begin{array}{l}\text { - Respirator performance maintained for } 10 \text { re-uses. }{ }^{[3,10,11]} \\
\text { - Large-volume processing is possible. }{ }^{[12]} \\
\text { - Allows for even penetration of vapour over entire respirator, as opposed to } \\
\text { UVGI, where there may be a shadow effect on some respirator surfaces. }{ }^{[5]} \\
\text { - Currently the most cost-effective from of gas sterilisation, }{ }^{[13]} \text { with low } \\
\text { toxicity. }{ }^{[10,14]} \\
\text { - Carcinogenic, but safe for use following an aeration period; can cause eye } \\
\text { damage if in contact. }{ }^{[15]} \\
\text { - Not compatible with material containing celluloses. } \\
\text { - Respirator straps may absorb hydrogen peroxide, causing low vapour } \\
\text { concentration and aborted cycle. }{ }^{[14]}\end{array}$ \\
\hline UVGI & $\begin{array}{l}\text { - A UV-C lamp emitting a minimum } \\
\text { effective dose of } 1.8 \mathrm{~J} / \mathrm{cm}^{2} \\
\text { - A reflective chamber or box }{ }^{[3,5]} \\
\text { - } 15 \text {-minute exposure time for each side } \\
\text { of the respirator }{ }^{[3,14,16]}\end{array}$ & $\begin{array}{l}\text { - UVGI application does not affect filtration performance, }{ }^{[3,5,16]} \text {, but may cause } \\
\text { elastic strap degradation. Avoid dose }>950 \mathrm{~J} / \mathrm{cm}^{[2]} \\
\text { - Respirator fit must be assessed following UVGI; } 90-100 \% \text { correct fit after } \\
\text { three cycles, depending on respirator type. } \\
\text { - A shadow effect (UV light not reaching within folds of respirators) can occur, } \\
\text { with incomplete decontamination. } .^{[5,17]} \\
\text { - Precautions taken to avoid UVGI exposure to eyes and skin. }{ }^{[5]}\end{array}$ \\
\hline $\begin{array}{l}\text { Microwave- } \\
\text { generated steam }\end{array}$ & $\begin{array}{l}\text { - Microwave (>1 } 100 \text { watts) } \\
\text { - Microwave steam bags (for sterilisation } \\
\text { of formula bottles) } \\
\text { - Run at a minimum of } 1100 \text { watts for } \\
90 \text { seconds in a bag filled with } 60 \mathrm{~mL} \\
\text { tap water }{ }^{[5,11]}\end{array}$ & $\begin{array}{l}\text { - Microwaves are widely available, but the method is limited to processing a } \\
\text { single respirator at a time. } \\
\text { - Has potential to rapidly decontaminate a respirator in the clinical area as } \\
\text { needed. } \\
\text { - Metal strip in respirators can cause sparks in the microwave. } \\
\text { - Microwaves differ in power output; the effect of higher power on respirator } \\
\text { integrity is unknown. } \text {. }^{[3,5,17]}\end{array}$ \\
\hline $\begin{array}{l}\text { Methods not } \\
\text { currently endorsed } \\
\text { owing to limited } \\
\text { evidence }\end{array}$ & $\begin{array}{l}\text { - Moist heat incubation: currently not recc } \\
\text { Incubation temperature of } 65^{\circ} \mathrm{C} \text { at } 85 \% \\
\text { - Mask rotation: each } \mathrm{HCW} \text { has a set nu. } \\
\text { whereafter virus is no longer viable and } \\
\text { - Ozone: requires an ozone generator an } \\
\text { concentrations. Need for aeration time. } \\
\text { - Other methods not recommended eith } \\
\text { liquid hydrogen peroxide/hydrogen per } \\
\text { irradiation; gamma irradiation; bleach. } \\
\text { other reasons. }\end{array}$ & $\begin{array}{l}\text { mmended owing to limited evidence of efficacy of killing various pathogens. }{ }^{[5,17]} \\
\text { relative humidity for } 30 \text { minutes. }{ }^{[3,5]} \\
\text { mber of respirators that they rotate use of. Respirators are dried for }>72 \text { hours, } \\
\text { the respirator can be re-used. }{ }^{[17]} \\
\text { Id a sealed box or chamber. }{ }^{[18]} \text { Very limited scientific literature. Toxic in high } \\
\text { 18-21] } \\
\text { er owing to lack of evidence of efficacy or damage to the respirator include: } \\
\text { oxide plasma; dry heat; } 70 \% \text { isopropyl alcohol; autoclave; soap; dry microwave } \\
3,5,11,14-18] \text { Ethylene oxide is not recommended as it may harm the wearer, among }\end{array}$ \\
\hline
\end{tabular}


1. World Health Organization. Coronavirus disease 2019 (COVID-19): Situation Report - 82. 11 April 2020. https://www.who.int/docs/default-source/coronaviruse/situation-reports/20200411-sitrep-82covid-19.pdf?sfvrsn=74a5d15_2 (accessed 18 April 2020).

2. Centers for Disease Control and Prevention. Characteristics of health care personnel with COVID-19 United States, February 12 - April 9, 2020. MMWR Morb Mortal Wkly Rep 2020;69(15):477-481. https://www.cdc.gov/mmwr/volumes/69/wr/pdfs/mm6915e6-H.pdf (accessed 18 April 2020).

. World Health Organization. Rational use of personal protective equipment for coronavirus disease (COVID-19) and considerations during severe shortages. 6 April 2020. https://www.who.in publications-detail/rational-use-of-personal-protective-equipment-for-coronavirus-disease-(covid19)-and-considerations-during-severe-shortages (accessed 16 April 2020).

4. Centers for Disease Control and Prevention. Strategies for optimizing the supply of N95 Respirators. Updated 2 April 2020. https://www.cdc.gov/coronavirus/2019-ncov/hcp/respirators-strategy/ index.html?CDC_AA_refVal=https\%3A\%2F\%2Fwww.cdc.gov\%2Fcoronavirus\%2F 2019ncov\% 2 Fhcp $\% 2$ Frespirators-strategy\% 2 Fcrisis-alternate-strategies.html (accessed 16 April 2020).

5. National Institute for Occupational Safety and Health, Centers for Disease Control and Prevention. Decont Decontaminaton and reuse of coronavirus/20 2020)

6. Centers for Disease Control and Prevention. Recommended guidance for extended use and limited reuse of N95 filtering facepiece respirators in healthcare settings. 27 March 2020. https://www.cdc.gov/ niosh/topics/hcwcontrols/recommendedguidanceextuse.html (accessed 16 April 2020).

7. National Department of Health, South Africa. COVID-19 disease: Infection prevention and control guidelines version 1. April 2020. http://www.health.gov.za/index.php/component/phocadownload/ category/626-infection-control-material (accessed 18 April 2020).

8. World Health Organization. Advice on the use of masks in the context of COVID-19. 6 April 2020. https://www.who.int/publications-detail/advice-on-the-use-of-masks-in-the-community-duringhome-care-and-in-healthcare-settings-in-the-context-of-the-novel-coronavirus-(2019-ncov)-outbreak (accessed 18 April 2020).

9. Centers for Disease Control and Prevention. Use of cloth face coverings to help slow the spread of Centers for Disease Control and Prevention. Use of cloth face coverings to help slow the spread of
COVID-19. 13 April 2020. https://www.cdc.gov/coronavirus/2019-ncov/prevent-getting-sick/diy-clothace-coverings.html (accessed 18 April 2020).

10. Batelle. Final report for Bioquell hydrogen peroxide vapor (HPV) decontamination for reuse of N95 respirators. 22 July 2016. https://www.fda.gov/media/136386/download (accessed 16 April 16 2020).

11. Bergman MS, Viscusi DJ, Heimbuch BK, Wander JD, Sambol AR, Shaffer RE. Evaluation of multiple (3-cycle) decontamination processing for filtering facepiece respirators. J Eng Fiber Fabr 2010;5(4):3341. https://doi.org/10.1177/155892501000500405
12. US Food and Drug Administration. Coronavirus (COVID-19) update: FDA issues emergency use authorization to decontaminate millions of N95 respirators. 12 April 2020. https://www.fda.gov/newsauthorization to decontaminate millions of N95 respirators. 12 April 2020. https://www.tda.gov/news-
events/press-announcements/coronavirus-covid-19-update-fda-issues-emergency-use-authorizationevents/press-announcements/coronavirus-covid-19-up
decontaminate-millions-n95 (accessed 16 April 2020).

13. Debabrata B, Chandra BS, Arijit D, Debdutta RJ, Gaurav G. Comparing sterilization efficacy and cost implications of various gas-based sterilization methods used in a central sterile supply department A short review. J Acad Clin Microbiologists 2018;20(2):108-110. https://doi.org/10.4103/jacm. jacm_1_18

14. Viscusi DJ, Bergman MS, Eimer BC, Shaffer RE. Evaluation of five decontamination methods for filtering facepiece respirators. Ann Occup Hyg 2009;53(8):815-827. https://doi.org/10.1093/annhyg/ mep070

5. Rutala WA, Weber DJ. Disinfection and sterilization in health care facilities: What clinicians need to know. Clin Infect Dis 2004;39(5):702-709. https://doi.org/10.1086/423182

16. Liao L, Xiao W, Yu X, et al. Can N95 facial masks be used after disinfection? And for how many times? Stanford: Stanford University and 4C Air Inc, 2020. http://web.stanford.edu/group/cui group/papers Lei_Cui_MEDARXIV_2020.pdf (accessed 16 April 2020).

17. Society of American Gastrointestinal and Endoscopic Surgeons (SAGES). N95 mask re-use strategies. 17 April 2020. https://www.sages.org/n-95-re-use-instructions/ (accessed 19 April 2020)

18. Dennis R, Cashion A, Emanuel S, Hubbard D. Ozone gas: Scientific justification and practical Dennis R, Cashion A, Emanuel S, Hubbard D. Ozone gas: Scientific justification and practical
guidelines for improvised disinfection using consumer-grade ozone generators and plastic storage boxes. J Sci Med 2020;2(1):1-23. https://doi.org/10.37714/JOSAM.V2I1.35

19. Fischer R, Morris DH, van Doremalen N, et al. Assessment of N 95 respirator decontamination and reuse for SARS-CoV-2. medRxiv 2020 (epub 24 April 2020). https://doi.org/10.1101/2020.04.11.20062018 20. Tseng C, Li C. Inactivation of surface viruses by gaseous ozone. J Environ Health 2008;70(10):56-62. https://pubmed.ncbi.nlm.nih.gov/18561570/ (accessed 28 April 2020).

21. Hudson JB, Sharma M, Vimalanathan S. Development of a practical method for using ozone ga as a virus decontaminating agent. Ozone Sci Eng 2009;31(3):216-223. https://doi.org/10.1080/ 01919510902747969

22. Centers for Disease Control and Prevention. Ethylene oxide 'gas' sterilization. 18 September 2016. https://www.cdc.gov/infectioncontrol/guidelines/disinfection/sterilization/ethylene-oxide.html (accessed 16 April 2020).

Accepted 27 April 2020. 